\title{
Landscape and Climate Role in the Formation of Sturgeon Reproduction Biotopes in the Ural River (Zhaiyk)
}

\author{
Ekaterina V. Mikodina ${ }^{1,}{ }^{*}$, Gulmira M. Shalgimbaeva ${ }^{2}$ and Alexander A. Volkov ${ }^{1}$ \\ ${ }^{1}$ Russian Federal Research Institute of Fisheries and Oceanography, Russian Federation \\ ${ }^{2}$ Fisheries Research and Production Center, Republic Kazakhstan
}

\begin{abstract}
Geoecology of the Ural River: landscape, climate, flora, and ichthyofaunal are given. Features of air and water temperature, winds, water sources, and balance are detailed. Information about Sturgeon fishes of the Acipenseridae family, the number of which is critical, is presented. The interaction of natural conditions and anthropogenic factors in the creature of spawning biotopes is described.
\end{abstract}

\section{Introduction}

The Ural River flows through the territories of two countries - The Russian Federation and the Republic of Kazakhstan, i.e., it is a transboundary one. Since 2018, the Russian-Kazakh Commission has been engaged in conserving the Ural River basin's ecosystem. The state of the reserves of joint transboundary species of Caspian Sea aquatic biological resources (ABR) their study, conservation, and reproduction is a priority [1].

\section{Materials and methods}

Analytical and expeditionary methods were used. Expedition works were located on the Republic of Kazakhstan's territory, held 15-23 September 2016, on West Kazakhstan and Atyrau regions. The depth of the river bed at the spawning grounds was measured with a GARMIN GPSMAP 580/585 echo sounder, the current velocity was measured with an ISP1 hydrometric spinner at the crossings of the surveyed spawning grounds, and the water temperature was measured at the sections of the channel spawning grounds with a laboratory water thermometer. The pilot's map of the Ural River [2] and Atlas of spawning grounds of sturgeon fishes of the Zaiyk River [3] were used.

\section{Results and discussion}

About 50 species of valuable pass-through, semi-pass-through and resident fish (Grayling Thymallus thymallus, Whitefish Coregonus lavaretus, Walleye Zander lucioperca, Bream Abramis brama, Common carp Cyprinus carpio, Roach Rutilus caspicus and Rutilus rutilus,

* Corresponding author: mikodina@,vniro.ru 
Crucian carp Carassius carassius, European catfish Silurus glanis, etc.) are considered to be transboundary aquatic biological resources (ABR) in the Ural River. However, first of all, these are the oldest Sturgeon fishes of the Acipenseridae family: Stellate Sturgeon (Acipenser stellatus), Russian Sturgeon (Acipenser gueldenstaedtii), Persian Sturgeon (Acipenser persicus), Beluga Sturgeon (Huso huso), Sterlet (Acipenser ruthenus) and Thorn Sturgeon (Acipenser nudiventris) because of they are the Cretaceous period relics. People have a long time called "red fish", i.e. they are delicious in taste, but not due to their meat color.

As well as more than two hundred years ago, when, according to P.S. Pallas [4], the Ural River was called «Sevruga River» because of Sevruga (Rus.) fish (=Stellate Sturgeon - eng.) predominates here, as other Sturgeon species, as well as in the Volga River and other sturgeon rivers, they are close to extinction [5]. Sturgeon fishery or "krasnolov'e" (=redfishing) is strictly prohibited not only in the Ural River of Kazakhstan and Russia but also for all 5 Caspian Sea countries.

The transboundary Ural River is divided by geographers and ecologists into three parts: upper, middle, and lower part of the flow [6]. Earlier, the spawning migration of Sturgeons, particularly the Beluga Sturgeon, reached the Ural River upper flow. At present, Sturgeon spawning grounds are sharply reduced and localized only in the lower river flow downstream of the Uralsk city, where it flows through the flat landscape of steppe, desertsteppe, and natural desert zones. In this respect, the Ural River's ecology lower flow is the same as the main sturgeon rivers in Russia, the Volga River, for example. Near $15 \mathrm{~km}$ from the Ural River confluence into the Caspian Sea, a delta, smaller in area and branches number then Volga River has, is formed, the main of which are Peretaska, Zolotoy, Yaitskiy, Bukharka. Spawning Sturgeon biotopes in the Ural River, called spawning bottom ridges, as ones in the Volga River [7] are coastal shoals with gravel pebble-sandy or dense clayey, shell soil, sometimes silted soil. The width of the river, on average ranges, is from 100 to $200 \mathrm{~m}$, the depth on the rifts $-0.3 \mathrm{~m}$, in the stretches up to $8 \mathrm{~m}$. The current speed on the stretches reaches $0.3-0.5 \mathrm{~m} / \mathrm{s}$, and on the rifts - up to $1 \mathrm{~m} / \mathrm{s}$ (at some $2 \mathrm{~m} / \mathrm{s}$ ).

Biotopes form and function under the influence of natural conditions (landscape, climate, hydrology) and anthropogenic factors (hydro-construction, illegal fishing (IUU fishing), artificial reproduction of Sturgeon fishes (Fig. 1). Anthropogenic factors affect the Sturgeon communities in this river according to the "plus-minus interaction" principle, when damage to them is compensated by Surgeon juveniles' release, obtained artificially at sturgeon hatcheries, into the Ural River. To minimize that damage, there are two stateowned Sturgeon hatcheries (S.H.) in the Atyrau region of the Republic of Kazakhstan: the Ural-Atyrau SH (on the left bank of the main channel) and the Atyrau S.H. (on the Yaitsky branch of the Ural River delta). They have located about $30 \mathrm{~km}$ from the Caspian coast near Atyrau city. These S.H.s annually release up to 7 million artificially obtained Sturgeon juveniles into Ural River natural conditions. 


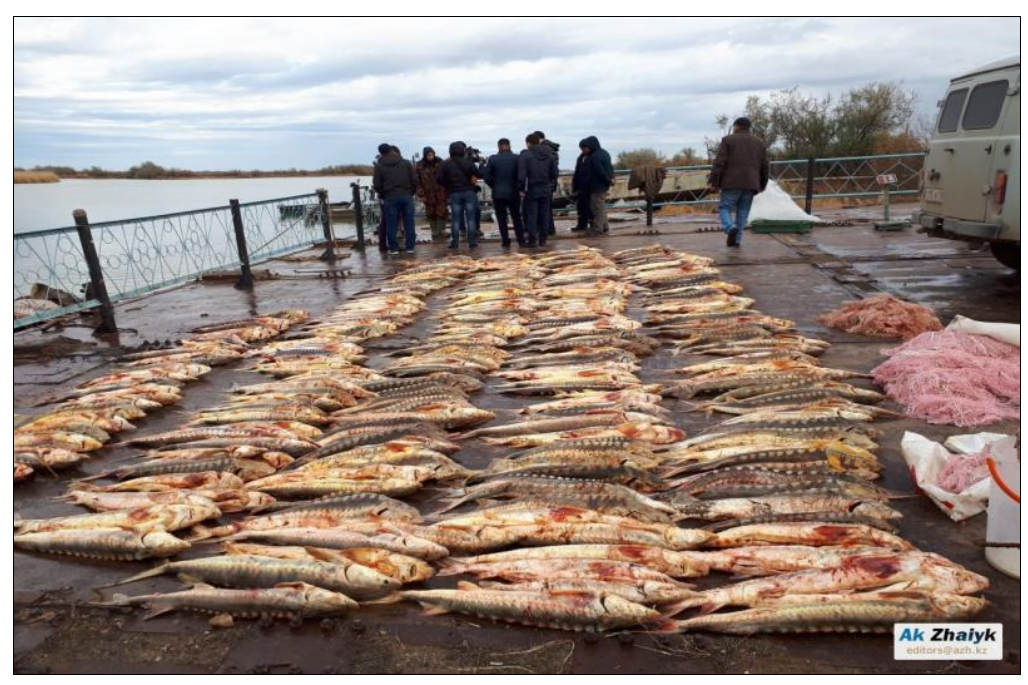

Fig. 1. Results of illegal (IUU) fishing in Ural River

Urals Sturgeons populations, being anadromous species, migrate into this river to carry out the critical parts of their life cycle - reproduction and wintering. Their spawning migrations are carried out either in the spring (early and late spring forms) or in the autumn (early and late winter forms). In winter, Sturgeons lie on bottom pits, the depth of which in the Ural River range from 4 up to $20 \mathrm{~m}$. The spawned individuals migrate back to the Caspian Sea for feeding, and the hatched offspring also rolls into the sea [8]. Thus, from one-third up to $3 / 4$ parts of their annual life cycle, the Ural sturgeon populations spend in the freshwater of this river. That is why it is essential to know the dynamics of changes in the Ural River's geoecology. Due to the rapid shallowing of the Ural River, this is of particular importance.

Earlier in the Russian Empire, based on the freshwater part of the Sturgeon life cycle, their fishing was strictly regulated. The Russian population of the lower flow of the Ural River -- Yaik (Ural) Cossacks, up to 1920s, were caught sturgeon only four times per year: in spring, in autumn, and twice in winter. Guided by the need to preserve the "red" fishing, fishermen observed the maximum possible caution and silence during the wintering and spawning period: in churches, it was even forbidden to ring bells [9]. Thus, the Sturgeon breeding success is still part of the conservation of the Ural River's aquatic ecosystem.

It is well known that fish biotopes are a regional component with the same landscape and climate. Due to its considerable length $(2428 \mathrm{~km})$, the Urals' river bed is formed and flows on different landscapes and climatic conditions. They, along with the anthropogenic influence of hydraulic technical structures, water consumption for agricultural and domestic needs (up to $60-85 \%$ ), determine the geoecology of the river: the morphology of the river channel, banks, rifts, ridges, depth, current velocity, level regime, shallowing, drying, incl. in spawning grounds, i.e., preservation of spawning biotopes [5]. In the Ural River, the conditions in the upper, middle, and lower parts differ so much in the degree of degradation that natural reproduction is possible only for $600 \mathrm{~km}$ from Oral (former Uralsk, Yaitskiy gorodok) downstream. This part of the river is a small part of the channel's middle and lower parts, where six spawning grounds have been preserved: Naydenovskoye, NizhneBarbastovskoye, Yablonevoye, Politovskoye, Inderskoye and Yamankhalinskoye [Fig. 2]. Simultaneously, only one of them is located in the Atyrau region and 5 - in the West Kazakhstan region $[8,10]$. The current speed here is $0.5-2.0 \mathrm{~m} / \mathrm{s}$ with soils in the form of crushed stone, gravel $(2-20 \mathrm{~mm})$, pebbles $(40-50 \mathrm{~mm})$, and depths from 4 to $10 \mathrm{~m}$ during 
the flood period. At present, only these natural spawning grounds, mainly Sevryuga Sturgeon, have survived in a relatively working condition [5].

The Urals River landscape in these territories is typical for arid regions: steppe, semidesert, and desert climatic zones. The banks in the upper flow are mountainous; in the lower ones, they are mostly sloping and flat, but cliffs are made of sandstone, claymudstones, and clayey limestones. The Ural River meanders, forming loops, islands, including "reclaimed" ones, as well as oxbows [Fig. 3]. Along the banks in the upper reaches is forest; in the lower, there are undersized shrubby and higher aquatic vegetation (cattail, reeds) [11].

The Ural-Caspian basin climate is formed under the influence of the radiation balance, circulation processes, and the nature of the underlying surface. The considerable distance from the Atlantic and Pacific Oceans determines the sharply continental climate in the basin. Under the influence of the Azores and Siberian anticyclones in winter, predominantly clear and cold weather is observed in most of the territory. Summers are hot, with a sharply increasing aridity with distance to the south [12]. Due to the very considerable length of the river. In the Ural, which is more than two thousand kilometers long, the air temperature changes as it moves from north to south. The average January temperature in the north of the basin is minus $14.3-15.4^{\circ} \mathrm{C}$, and in the south - minus $4.0^{\circ}$ C. The warmest month is July: from $20.5^{\circ} \mathrm{C}$ in the north up to $29.2^{\circ} \mathrm{C}$ in the south.

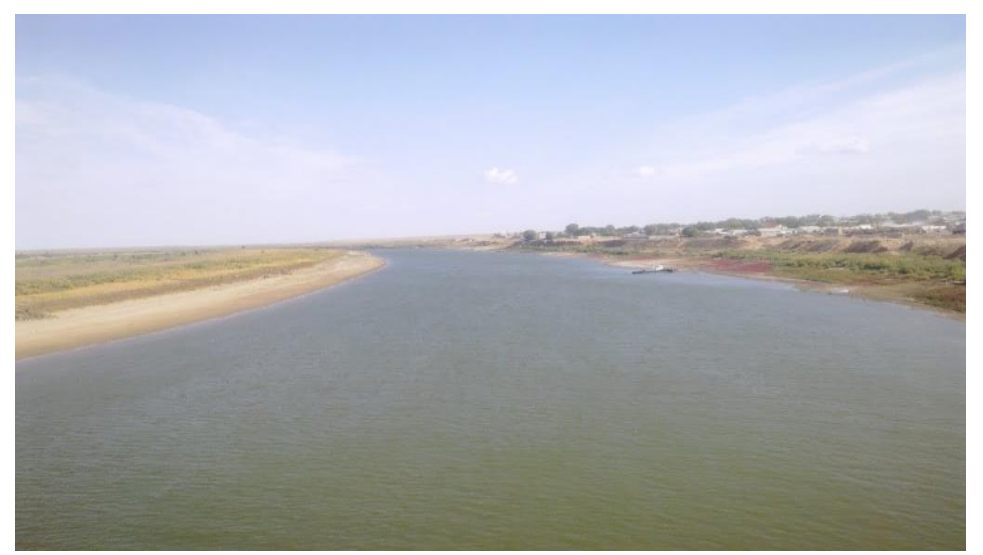

Fig. 2. Sevruga (Acipenser stellatus) spawn ridge at the left bank of the Ural River near Inder village at $270 \mathrm{~km}$ from its delta

The average long-term annual values of the relative air humidity in the territory under consideration vary from $72 \%$ (in the north) to $56 \%$ (in the south). The maximum relative humidity values are observed in winter (up to $88 \%$ ), the lowest - in the warm season (up to $35 \%$ ). The average long-term annual deficit of air humidity ranges between $4.6-11.6 \mathrm{hPa}$. The variety of climatic and orographic conditions of the basin predetermines the uneven distribution of precipitation over its territory. The average long-term amount of annual precipitation amounts varies from $300-380 \mathrm{~mm}$ in the north to $130-180 \mathrm{~mm}$ in the south [12].

The Ural River basin belongs to the area with snow cover for 2.5-5 months a year, except for the Atyrau region, where snow is observed in less than $50 \%$ of winters. Snow cover appears from the second half of October to early November in the northeast to the first decade of December in the south. The most intense snow accumulation usually lasts until mid-February - mid-March. Maximum snow reserves in the Cis-Urals reach $210 \mathrm{~mm}$, decreasing to $30 \mathrm{~mm}$ with distance to the south. 
The wind regime is determined by baric-circulation factors, orography and is somewhat different. In the cold season, the northeastern regions of the river basin are under the influence of the Siberian anticyclone spur; the winds of the southern $(20 \%)$ and southwestern (16\%) points prevail here. The southwestern part of the river basin is exposed to cyclones from the Caspian, the effect of which is weakened with the prevalence of east $(18 \%)$ and southeastern $(15 \%)$ winds. In the warm season, a restructuring of the baric field occurs with a change in the wind regime throughout the territory.

For the sturgeon breeding period, the wind speed in April-May must be significant, and dry winds bring sand into the spawning ridges [8]: in May, the average monthly speed is 4$6 \mathrm{~m} / \mathrm{s}$; in summer, it varies between $2-4 \mathrm{~m} / \mathrm{s}$. Mountain-valley winds occur in mountainous regions. Breezes are observed in the Caspian coastal strip in summer [12]. The Ural River and its tributaries annual flow is formed under the influence of climatic factors, the water content of the drainage basin, and the intensity of ice and snow melting in spring. According to the water regime's conditions, the Ural River belongs to the Kazakhstan type with a pronounced predominance of runoff in the spring.

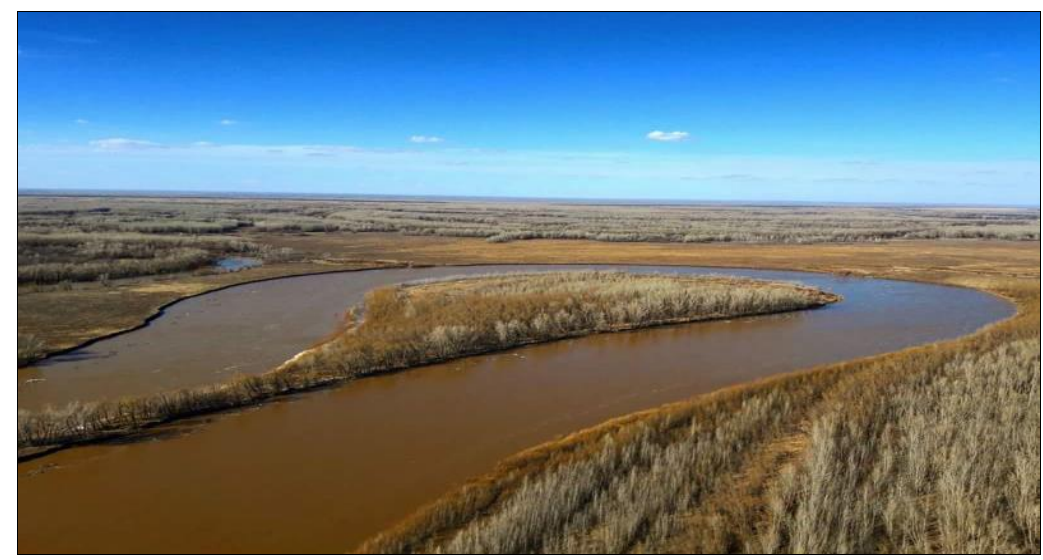

Fig. 3. The Ural River curving bed and vegetation along its banks in autumn, 2020

The highest annual water discharge is most often observed in the second half of April and occasionally in early May. The share of the spring runoff from the annual in various regions ranges from 55 to $100 \%$. It reaches its highest value in the southwestern part, where it is $95-98 \%$ and the lowest in the upper part of the Ural (Zhaiyk) River basin. The duration of the rise of high water on small streams is usually 1-3 days, on medium $-8-12$, and relatively large - 20-30 days. When the snow melts together in late springs, the flood is highest; in early springs, when the snow melts gradually, it is low. On tributaries of the upper and partially middle reaches of the Ural River, floods usually end in late April - early May, directly in the river Ural - late May - early June. After the end of the spring flood, a summer-autumn low water period sets in on the rivers. The Ural region's drainage basin is of the Kazakhstan type and has a pronounced predominance of runoff in the spring. The highest annual water discharge is most often observed in the second half of April and occasionally in early May. On rivers with runoff throughout the year, the minimum discharge is observed in December-March. The share of the spring runoff from the annual in various regions ranges from 55 to $100 \%$. It reaches its highest value in the southwestern part, accounting for 95-98\%, and the lowest in the upper part of the Ural (Zhaiyk) River basin. The duration of the rise of high water on small streams is usually 1-3 days, on medium $-8-12$, and relatively large - 20-30 days [11]. Under the condition of longstanding high water horizons and spawning water temperatures ranging from 19 to $20{ }^{\circ} \mathrm{C}$, sturgeon spawning was ensured practically on all the remaining spawning ridges [12]. 


\section{Conclusions}

Thus, the main climatic factors that determine the value of the annual Ural River runoff are snow reserves in the basin at the beginning of snow melting, rainfall during floods, the degree of moisture, and soil freezing depth. In late springs, with amicable snow melting, the flood is highest; in early springs, when the snow melts gradually, it is low. The high water usually ends in late April - early May, on large rivers - in late May - June - the sturgeon fish breeding period. After the end of the spring flood, a summer-autumn low-water period sets in on the river. This period is favorable for fry not only in terms of feeding but also in the process of their catadromous migration in shallow water from the channel of the Ural River to the Caspian Sea.

The authors are deeply grateful to all Russian and Kazakh participants of joint expeditions and coauthors of publications. Special thanks to the researchers, whose publications on the Ural (Zhaiyk) River we used, without having some important information.

\section{References}

1.http.: Unece.org/Rivers_Study_in_Kazakhstan_Ural_River_(Feb., 2017)).

2. F.F. Ignatov, R.V. Telyatov. Pilot's map of Ural River (Kazakhstan Publishing, AlmaAta, 1978) (in Russian).

3. G.M. Shalgimbayeva, S.Zh. Asylbekova, E.B. Bokova, A.I. Kim, N.B. Bulavina,m Spawning grounds of sturgeon fishes of the Zhaiyk river: Atlas. K.B. Isbekov (ed.). (Almaty, 2017).

4. P.S. Pallas. Travel to different provinces of the Russian State, 1, 424-426 (IAS SPb., 1773) (in Russian).

5. G.M. Shalgimbaeva, N.S. Mugue., E.V. Mikodina, A.A. Volkov, Modern problems and prospects for the development of the fishery complex: Proceedings of VII SPCYSIP, 512-514 (VNIRO Publishing, Moscow, 2019)

6. A.A. Chibilev, The Urals basin: history, geography, ecology (Publishing house UB RAS, Yekaterinburg, 2008)

7. V.A. Kalmykov, G.I. Ruban, D.S. Pavlov, Journal of Ichthyology, 50(1_), 48-55 (2010) (in Russian)

8. A.D. Kamelov, N.N. Popov, Fish farming and fisheries, 5(148), 8-14 (2018) (in Russian).

9. N.A. Borodin, Ural Cossacks and their fishing (SPb., 1901) (in Russian).

10. E.B. Bokova, G.M. Shalgimbaeva, G.G. Dzhunusova, Proceedings ORSPC, 241-246 (Pero Publishing, Moscow, 2017) (in Russian).

11. E.V. Mikodina, G.M. Shalgimbaeva, Proceedings XXI ISPC, 1, 142-145 (Moscow, 2020) (in Russian).

12. I.B. Wolftsun, K.I. Smirnoff. (Eds.). Surface water resources of the USSR. Lower Volga and Western Kazakhstan. 12. II. Ural-Emba region (Leningrad, 1970) (in Russian). 